\title{
The Occurrence of Pecan Kernel Necrosis
}

\author{
Michael W. Smith ${ }^{1,3}$, Becky S. Cheary ${ }^{2}$, and Becky L. Carroll ${ }^{2}$ \\ Department of Horticulture and Landscape Architecture, Oklahoma State \\ University, Stillwater, OK 74078
}

Additional index words. Carya illinoinensis, nitrogen, nitrate, leaf elemental concentration, kernel disorder, cotyledon, kernel development, yield, production, nutrition

\begin{abstract}
Pecan [Carya illinoinensis (Wangenh.) C. Koch] kernels (cotyledon) of 'Pawnee' displayed a consistent malady not described previously that was designated as "kernel necrosis." The most severe form of the problem was blackened, necrotic tissue engulfing the basal one-half to one-third of the kernel. The mildest form was darkened tissue in the dorsal grove at the basal end of the kernel. The problem was first observable during the gel stage of kernel development. No symptoms of kernel necrosis were visible on the shuck (involucre). Kernel necrosis was more prominent on 'Pawnee', 'Choctaw', and 'Oklahoma' than other cultivars observed. At maturity, nuts with kernel necrosis had a larger volume than nuts with normal kernels. There were few differences in elemental concentrations of normal kernels from a severely affected orchard and an orchard with little kernel necrosis, and none of the differences appeared to be associated with this disorder. 'Pawnee' kernels with necrosis had more phosphorus, zinc, and manganese than normal kernels. Basal segments of necrotic kernels had more boron and acetic acidextractable and water-soluble calcium than distal segments or normal kernels. Higher elemental concentrations in basal segments of necrotic kernels did not appear sufficient to cause tissue damage.
\end{abstract}

Soil from the orchard with severe kernel necrosis had unusually high concentrations of nitrate, expressed as nitrogen $\left(\mathrm{NO}_{3}-\mathrm{N}\right)$, in the soil profile. Groundwater used for irrigation was contaminated with $34 \mathrm{mg} \cdot \mathrm{L}^{-1} \mathrm{NO}_{3}-\mathrm{N}$. An experiment on 'Pawnee' evaluated three nitrogen $(\mathrm{N})$ rates, $0,0.8 \mathrm{~g} \cdot \mathrm{cm}^{2}$ cross-sectional trunk area applied in March, and $1.6 \mathrm{~g}+1.6 \mathrm{~g}+1.2 \mathrm{~g} \cdot \mathrm{cm}^{2}$ cross-sectional trunk area $\mathrm{N}$ applied during the second week in March, first week in June, and first week in September, respectively, on the incidence of kernel necrosis, leaf $\mathrm{N}$ concentration, soil $\mathrm{NO}_{3}$ concentration, yield, nut quality, and growth over 5 years. Leaf $N$ was affected by treatment only once during the study. Nitrates accumulated in the soil, increasing $24 \%$ in 3 years when no supplemental $\mathbf{N}$ was applied, except in the contaminated irrigation water. Kernel necrosis was either unaffected by $N$ treatment or during 1 year, kernel necrosis was highest without supplemental $N$ application. Tree yield, kernel quality, and growth were unaffected by $\mathbf{N}$ treatment. Yield fluctuations among years were apparent demonstrating that an abundant $N$ supply did not prevent alternate bearing. Kernel necrosis was a severe problem in one orchard and was identified in several orchards at low frequencies. The cause of kernel necrosis remains unknown.

A persistent kernel quality problem was identified on pecan by a producer located in Charlie, TX. The tissue at the basal (stem) end of the kernel was necrotic and black in appearance (Fig. 1). Frequent observations by the producer and subsequently by us suggested that the problem could be first detected when the fruit was entering the gel stage (cellular endosperm) of development. A darkening of the testa first developed in the

\footnotetext{
Received for publication 14 Feb. 2007. Accepted for publication 1 Apr. 2007.

Funding for this study was provided by the Oklahoma Agricultural Experiment Station, Texas Pecan Board, and the Oklahoma Pecan Growers' Association.

Approved for publication by the Oklahoma Agricultural Experiment Station.

${ }^{1}$ Regents Professor.

${ }^{2}$ Senior Agriculturists.

${ }^{3}$ To whom reprint requests should be addressed; e-mailmike.smith@okstate.edu.
}

dorsal groove at the basal end of the kernel. As the problem became more severe, the necrotic tissue spread into the cotyledon and outside the dorsal groove. In the most severe instances, the entire basal section of the kernel was affected. The necrotic tissue rarely extended over more than the basal onehalf of the kernel and more typically encompassed the basal one-third when necrosis was severe. No symptoms were observed on the shuck when kernels were necrotic. Darkened tissue on the kernel sometimes extended farther on the ventral than dorsal side of the kernel (Fig. 2); however, the discoloration was first detectable on the dorsal side.

Black, necrotic areas on pecan kernels are incited by phytophagous stink bugs and coreid bugs [Hemiptera (Heteroptera)] (Yates et al., 1991). These necrotic areas are both different in appearance than kernel necrosis and occur on any region of the kernel. Feeding punctures as the fruit enters the gel or dough stage (deposition of cotyledon material) are characteristically irregular in shape and cover a larger area of the kernel than punctures at later stages of fruit development. The punctures that occur in the latter stages of development are round with welldefined edges. Pecan weevil [Curculio caryae (Horn)] also can cause kernel discoloration during feeding or probing the fruit for oviposition suitability (Harris and Ring, 1979). Female weevil most often probe the distal end of the fruit when feeding or seeking an oviposition site. Punctures during early cotyledon development cause irregular-shaped discoloration, similar to stink bug, and later punctures into the kernel are normally accompanied with egg deposition and larvae development. Excessive crops and other stresses can also cause poorly filled kernels (Smith and Gallott, 1990), but kernel appearance is different from the distinct blackening and specific location of the injury (Fig. 1).

The producer's testimony followed by inspection of nuts confirmed that this was a significant economic problem in this 140-ha orchard. Because the problem was unknown, several approaches were used to gain insight into the extent and cause of this malady.

\section{Materials and Methods}

Diagnostic tests. The first objective was to determine if this problem was limited to certain cultivars and if similar symptoms were present on nuts from other locations. Four hundred nuts each were collected in 2001 from field-run (not cleaned) pecans of four cultivars at Charlie, TX: 'Pawnee', 'Choctaw', 'Cheyenne', and 'Wichita', and two cultivars near Ardmore, OK: 'Pawnee' and 'Choctaw'. Ardmore is located $\approx 115 \mathrm{~km}$ east of Charlie. Average temperature during the growing season is nearly identical for the two sites, but Ardmore receives $\approx 5 \mathrm{~cm}$ more rainfall during the growing season than Charlie (Board of Regents Oklahoma University, 2006).

Nut volume was measured by submerging nuts individually in a graduated cylinder and recording the water displacement. Kernel halves (800) were then graded for the presence of necrosis using a 1 to 4 scale (Fig. 1) in which 1 was no necrosis and 4 was severe necrosis. In addition, numerous cultivars at other Oklahoma orchards have been observed over the last 6 years for the presence of this disorder.

Kernels were segregated into those with no symptoms and those with a necrosis grade of 3 or 4 . Kernels were then divided proximally for elemental analysis of the basal and distal kernel halves, then finely ground, and stored frozen. Samples were dried at $70{ }^{\circ} \mathrm{C}$ for $24 \mathrm{~h}$, and then extracted with either $2 \%$ acetic acid (Gallaher and Jones, 1976) or water (English and Barker, 1982; Faust et al., 1968) for calcium (Ca) analysis by atomic absorption spectroscopy. A second sample aliquot was dry-ashed in a muffle furnace and then analyzed for phosphorus (P) (Olsen and Sommers, 1982) and boron (B) (Dible et al., 1954) colorimetrically, and potassium $(\mathrm{K})$, magnesium $(\mathrm{Mg})$, zinc $(\mathrm{Zn})$, iron $(\mathrm{Fe})$, and 


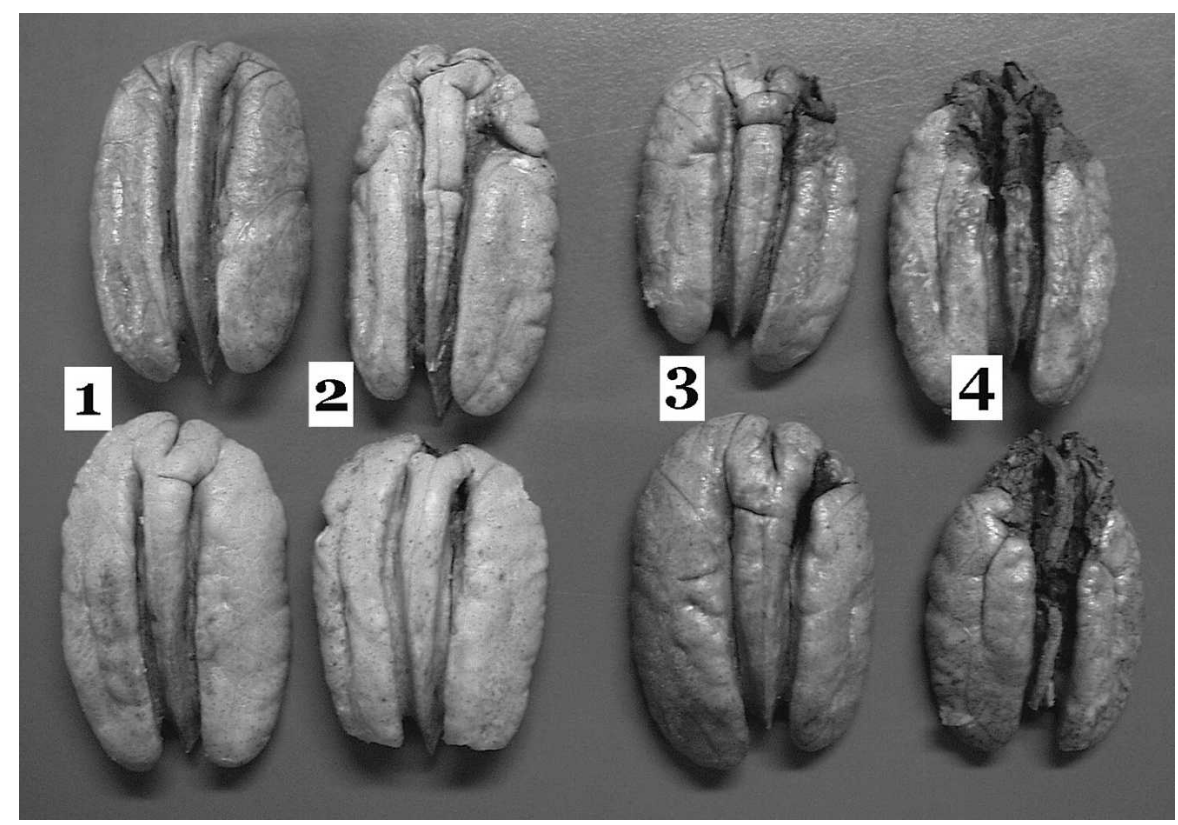

Fig. 1. Grades of 'Pawnee' pecan kernel with necrosis. From left to right: grade 1 normal kernels; grade 2 has a darkened area in the dorsal grove at the basal (stem) end of the kernel; grade 3 has a darkened, necrotic area progressing outside of the dorsal grove at the basal end; and grade 4 encompasses the entire basal portion of the kernel.

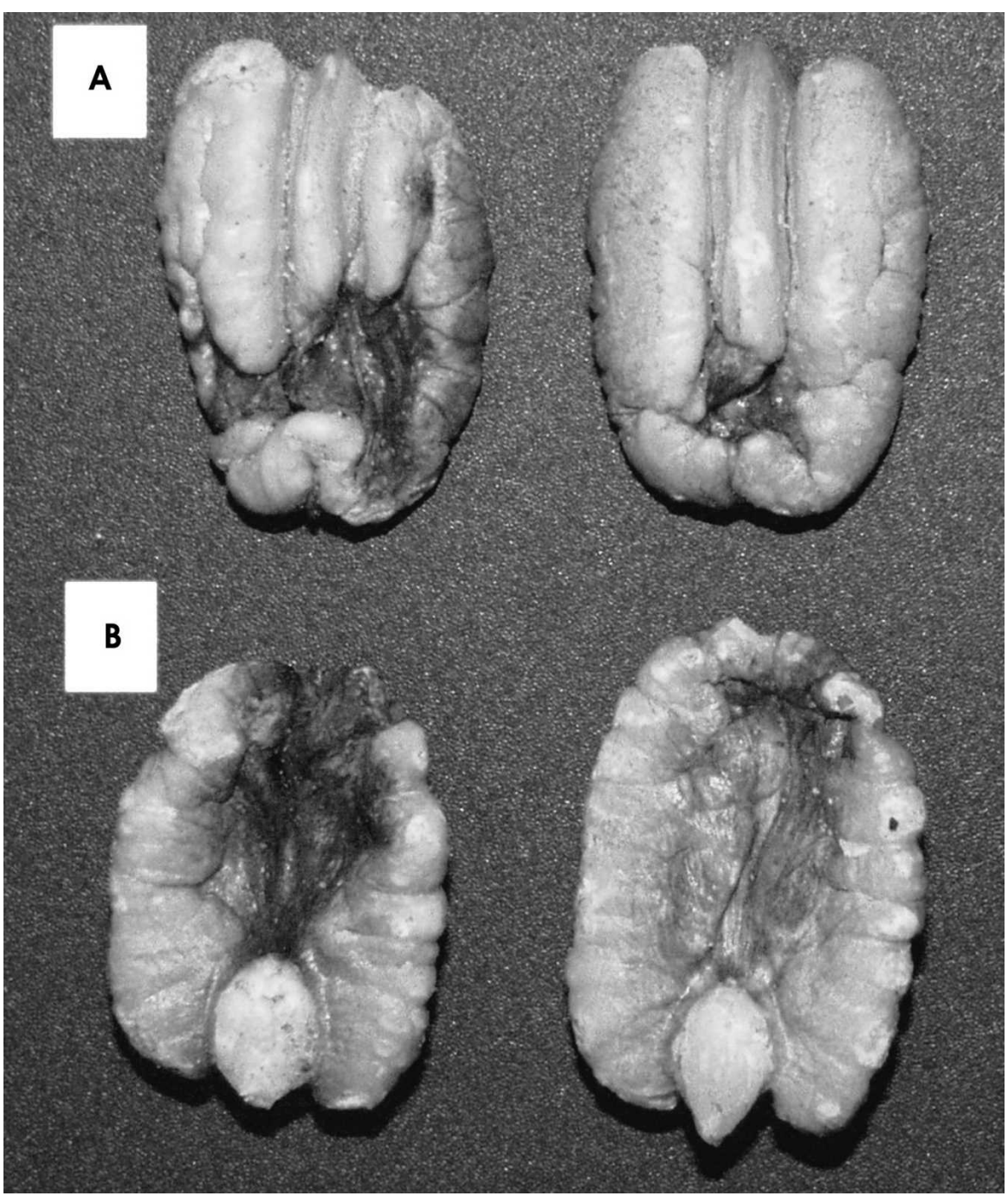

Fig. 2. The (A) dorsal and (B) ventral side of 'Pawnee' pecan kernels with necrosis symptoms. manganese $(\mathrm{Mn})$ by atomic absorption spectroscopy. Elemental analysis for each treatment combination (disorder $\times$ cultivar $\times$ kernel part $\times$ location) was replicated four times.

Soil and water samples were collected and submitted for analysis by the Soil, Forage and Water Testing Laboratory at Oklahoma State University. Soil samples were collected during Jan. 2002 at $0-15,15-30$ and 30-45-cm depths using a standard soil probe. Samples were from six randomly chosen sites in the orchard at Charlie. Soil from at least 10 probes were composited by depth for each site. Samples were analyzed for $\mathrm{pH}, \mathrm{NO}_{3}-\mathrm{N}$, $\mathrm{P}, \mathrm{K}, \mathrm{Ca}, \mathrm{Mg}, \mathrm{Zn}, \mathrm{Fe}$, and B. Water samples were collected from an irrigation well in January and then monthly during the growing season. Water was analyzed for sodium $(\mathrm{Na})$, $\mathrm{Ca}, \mathrm{Mg}, \mathrm{K}, \mathrm{NO}_{3}-\mathrm{N}$, chloride, sulfate, $\mathrm{B}$, bicarbonate, $\mathrm{pH}$, electrical conductivity, and total salts. The $\mathrm{Na}$ absorption ratio, $\mathrm{K}$ absorption ratio, $\mathrm{Na}$ percentage, hardness, and alkalinity were then calculated.

Nitrogen rate experiment. An $\mathrm{N}$ rate study was initiated 2002 on 'Pawnee' trees located in the orchard with the kernel necrosis. Treatments were no supplemental $\mathrm{N}, 0.8 \mathrm{~g} \cdot \mathrm{cm}^{2}$ cross-sectional trunk area $\mathrm{N}$ applied in March and $1.6 \mathrm{~g}+1.6 \mathrm{~g}+1.2 \mathrm{~g} \cdot \mathrm{cm}^{2}$ cross-sectional trunk area $\mathrm{N}$ applied during the second week in March, first week in June, and first week in September, respectively. The last treatment simulated the producer's $\mathrm{N}$ application program. Nitrogen fertilizer was distributed evenly by hand under the tree canopy. Treatments were replicated 18 times in a randomized complete block design using single-tree plots.

Trees were 14 years old when the study was initiated. Spacing was $12.2 \times 12.2 \mathrm{~m}$ with rows oriented north-south. The soil was a Teller sandy loam (fine-loamy, mixed, active, thermic, Udic Argiustolls). Irrigation was by microsprinklers that covered $\approx 80 \%$ of the orchard floor. A single $200 \mathrm{~L} \cdot \mathrm{h}^{-1}$ sprinkler was located between trees in the row middle. Irrigation frequency was determined by the producer. The orchard floor was maintained vegetation-free throughout the growing season with multiple applications of glyphosate [N-(phosphonomethyl) glycine]. No winter cover crops were used. Trees were pruned with a mechanical hedger annually on the east and west sides and the top.

Leaf samples were collected annually for each tree in July using the middle leaflet pair from the middle leaf on the current season growth as the index tissue. Samples were washed in deionized water, dried at $70{ }^{\circ} \mathrm{C}$, ground to pass a 20-mesh screen, and stored in glass jars until analyzed. Organically bound $\mathrm{N}$ was analyzed by the macro-Kjeldahl method (Horowitz, 1980), P colorimetrically (Olsen and Sommers, 1982), and K, Ca, Mg, $\mathrm{Zn}, \mathrm{Fe}$, and $\mathrm{Mn}$ were analyzed by atomic absorption.

Soil samples were collected during January in 2003, 2004, and 2006 using a standard soil probe. Samples were collected at 0-15, 15-30, and 30-45-cm depths. Each tree was probed five times, and soil from trees with 
like treatments from three replications were combined. Thus, each treatment was represented by six replications with 15 soil cores per replication at each depth. Samples were analyzed for $\mathrm{NO}_{3}-\mathrm{N}$ by the Soil, Forage and Water Testing Laboratory at Oklahoma State University.

At fruit maturity, nuts were dislodged from the tree with a mechanical shaker and then hand-harvested. Individual tree yields were recorded and samples collected for necrosis rating (Fig. 1), weight/nut and kernel percentage from the field-run nuts before cleaning. Nut weight, kernel necrosis, and kernel percentage were determined on duplicate 20-nut samples per tree.

Trunk diameter $1.4 \mathrm{~m}$ above the ground was measured annually during dormancy. Shoot length of the longest shoot per 1year-old branch was measured while dormant on 30 shoots per tree during 2002 through 2004.

Data were analyzed using analysis of variance with mean separation by Duncan's multiple range test. In addition, the relationship of kernel necrosis with yield, and leaf $\mathrm{N}$, $\mathrm{P}, \mathrm{K}, \mathrm{Ca}, \mathrm{Mg}, \mathrm{Zn}, \mathrm{Fe}, \mathrm{Mn}, \mathrm{N} / \mathrm{K}, \mathrm{N} / \mathrm{P}, \mathrm{N} / \mathrm{Ca}$, and $\mathrm{N} / \mathrm{Mg}$ for the linear, quadratic, and logarithmic functions was determined using a stepwise regression model selection technique for individual years and all data pooled.

\section{Results and Discussion}

Diagnostic test results. Kernel necrosis (Fig. 1) was more prevalent on 'Pawnee' from Charlie, TX, than on the other cultivars from Charlie (Table 1). 'Choctaw' at Charlie also had a substantial amount of kernels with necrosis. Neither 'Pawnee' nor 'Choctaw' at Ardmore had appreciable amounts of kernel necrosis, although a few kernels with similar symptoms were identified. Observations over the past 6 years agree with results obtained in 2001. An observation while processing the nuts was that if one kernel half had necrosis, then the other half was likely to have some degree of necrosis.

The problem at Charlie was prevalent on 'Pawnee', at times a significant problem on 'Choctaw', and although similar symptoms occur on 'Cheyenne' and 'Wichita', the frequency was low enough to not be considered a significant problem. Similar symptoms have been identified on 'Pawnee' nuts in Oklahoma orchards at Madill, Perkins, Bixby, Luther, Muskogee, and Cleveland.

Table 1. The influence of pecan cultivar and location on the frequency of kernels with blackened, necrotic tissue at the basal end of the nut in 2001.

\begin{tabular}{llc}
\hline Location & Cultivar & Necrotic kernels (\%) \\
\hline Charlie, TX & Pawnee & $18.2^{\mathrm{z}}$ \\
& Choctaw & 9.0 \\
& Cheyenne & 0 \\
& Wichita & 0.3 \\
Ardmore, OK & Pawnee & 0.3 \\
& Choctaw & 0.3 \\
\hline
\end{tabular}

${ }^{\mathrm{z}}$ Four hundred nuts with 800 kernel halves examined per location and cultivar.
However, in each case, the number of kernels affected has been small, normally less than $0.3 \%$. This problem has not alarmed other producers, but does exist in small amounts.

At Luther, OK, several 'Oklahoma' kernels had similar symptoms. The producer indicated that this was a common problem on 'Oklahoma', but similar symptoms were either not present or rare on the other cultivars at this site. Observations combined with input from producers suggest that this primarily occurs on three cultivars in significant quantities: 'Pawnee', 'Choctaw' and 'Oklahoma'. 'Oklahoma' is a native seedling from Darden, OK (Thompson and Young, 1985). 'Pawnee' and 'Choctaw' have ancestry in common. 'Choctaw' is a cross between 'Success' and 'Mahan'. One of 'Pawnee's parents, 'Mohawk', is also a 'Success' and 'Mahan' cross. Both 'Success' and 'Mahan' are no longer planted because of poor kernel development as trees matured, and few trees of these two cultivars remain in Oklahoma. The common lineage suggests a genetic basis for susceptibility to kernel necrosis. Kernel necrosis was more pronounced at the Charlie orchard than the other locations, suggesting that the unique environmental conditions imposed on cultivars at this site combined with a genetic predisposition for the disorder resulted in an economic problem on 'Pawnee' and 'Choctaw' but not 'Cheyenne' and 'Wichita'.

Table 2. Volume of nut with normal kernel and those with kernel necrosis from two pecan cultivars in 2001

\begin{tabular}{lccc}
\hline Cultivar & $\begin{array}{c}\text { Kernel } \\
\text { necrosis }\end{array}$ & $\begin{array}{c}\text { No. of nuts } \\
\text { observed }\end{array}$ & $\begin{array}{c}\text { Nut volume } \\
(\mathrm{mL}) \bar{x} \pm \mathrm{SE}\end{array}$ \\
\hline Pawnee & No & 72 & $17.2 \pm 0.2$ \\
& Yes & 327 & $18.6 \pm 0.2$ \\
Choctaw & No & 364 & $22.6 \pm 0.1$ \\
& Yes & 36 & $24.1 \pm 0.5$ \\
\hline
\end{tabular}

Table 3. Elemental concentrations of the distal and basal sections of normal Pawnee pecan kernels from Charlie, TX, and Ardmore, OK, in 2001.

\begin{tabular}{|c|c|c|c|c|c|c|c|c|c|c|}
\hline \multirow[b]{2}{*}{ Location } & \multirow[b]{2}{*}{$\begin{array}{c}\text { Kernel } \\
\text { segment }\end{array}$} & \multicolumn{9}{|c|}{ Elemental concn $(\mu \mathrm{g} / \mathrm{g}$ dry wt. $)$} \\
\hline & & $\mathrm{P}$ & $\mathrm{K}$ & $\begin{array}{c}\text { Acetic acid } \\
\text { ext. } \mathrm{Ca}\end{array}$ & $\begin{array}{l}\text { Water } \\
\text { ext. Ca. }\end{array}$ & $\mathrm{Mg}$ & $\mathrm{Zn}$ & $\mathrm{Fe}$ & $\mathrm{Mn}$ & B \\
\hline \multirow[t]{2}{*}{ Charlie } & Basal & 2583 & 3123 & 347 & 188 & 1141 & 26 & 26 & 41 & 5 \\
\hline & Distal & 2553 & 3100 & 359 & 256 & 1191 & 25 & 21 & 42 & 5 \\
\hline \multirow[t]{2}{*}{ Ardmore } & Basal & 2386 & 3023 & 258 & 75 & 1045 & 28 & 17 & 51 & 4 \\
\hline & Distal & 2529 & 3004 & 292 & 80 & 1105 & 30 & 19 & 68 & 4 \\
\hline \multirow{3}{*}{\multicolumn{2}{|c|}{$\begin{array}{l}\text { Charlie versus Ardmore } \\
\text { Basal versus distal } \\
\text { Interaction }\end{array}$}} & NS & NS & $* *$ & $* * *$ & $*$ & NS & NS & $*$ & $* *$ \\
\hline & & NS & NS & NS & NS & NS & NS & NS & NS & NS \\
\hline & & NS & NS & NS & NS & NS & NS & NS & NS & NS \\
\hline
\end{tabular}

Ns,,$* * * * * * *$ Nonsignificant or significant at $5 \%, 1 \%$, or $0.1 \%$, respectively.

Table 4. Elemental concentrations of the distal and basal sections of normal and necrotic Pawnee pecan kernels from Charlie, TX, in 2001.

\begin{tabular}{|c|c|c|c|c|c|c|c|c|c|c|}
\hline \multirow[b]{2}{*}{$\begin{array}{l}\text { Kernel } \\
\text { necrosis }\end{array}$} & \multirow[b]{2}{*}{$\begin{array}{c}\text { Kernel } \\
\text { segment }\end{array}$} & \multicolumn{9}{|c|}{ Elemental concn $(\mu \mathrm{g} / \mathrm{g}$ dry wt. $)$} \\
\hline & & $\mathrm{P}$ & K & $\begin{array}{l}\text { Acetic acid } \\
\text { ext. } \mathrm{Ca}\end{array}$ & $\begin{array}{l}\text { Water } \\
\text { ext. Ca. }\end{array}$ & $\mathrm{Mg}$ & $\mathrm{Zn}$ & $\mathrm{Fe}$ & $\mathrm{Mn}$ & B \\
\hline \multirow[t]{2}{*}{ No } & Basal & 2583 & $3123 a^{z}$ & $347 \mathrm{a}$ & $188 \mathrm{a}$ & 1141 & 26 & 26 & $41 \mathrm{a}$ & $5 \mathrm{a}$ \\
\hline & Distal & 2553 & $3100 \mathrm{a}$ & $359 a$ & $256 \mathrm{~b}$ & 1191 & 26 & 21 & $42 \mathrm{a}$ & $5 \mathrm{a}$ \\
\hline \multirow[t]{2}{*}{ Yes } & Basal & 2875 & $6509 \mathrm{c}$ & $860 \mathrm{c}$ & $414 \mathrm{c}$ & 1378 & 29 & 29 & $87 \mathrm{c}$ & $10 \mathrm{~b}$ \\
\hline & Distal & 3339 & $3713 \mathrm{~b}$ & $485 \mathrm{~b}$ & $248 \mathrm{~b}$ & 1331 & 29 & 24 & $68 \mathrm{~b}$ & $6 \mathrm{a}$ \\
\hline \multirow{3}{*}{\multicolumn{2}{|c|}{$\begin{array}{l}\text { None versus necrosis } \\
\text { Basal versus distal } \\
\text { Interaction }\end{array}$}} & $* *$ & $* * *$ & $* *$ & $*$ & $* * *$ & $*$ & NS & $* *$ & $* * *$ \\
\hline & & NS & $* * *$ & NS & NS & NS & NS & NS & NS & $* * *$ \\
\hline & & NS & $* * *$ & $*$ & $*$ & NS & NS & NS & NS & $* * *$ \\
\hline
\end{tabular}

${ }^{\mathrm{z}}$ Mean separation by Duncan's multiple range test, $5 \%$ level.

Ns, ${ }^{* * *, * * * *}$ Nonsignificant or significant at $5 \%, 1 \%$, or $0.1 \%$, respectively.
Volume of nuts with kernel necrosis was 'Pawnee' nuts with kernel necrosis averaged $8 \%$ larger and 'Choctaw' $7 \%$ larger. This size difference was not sufficient to be identified visually or useful for segregating nuts. Howwith a necrosis grade of 1 or 2 and those with a grade of 3 or 4 was sufficient that the with segregate the forced air separator of his own design. These were processed in the separator after the nuts had undergone normal cleaning and drying procedures. e were similar in normal kernels from kernels from Charlie (Table 3). Normal extractable $\mathrm{Ca}$ and water-extractable $\mathrm{Ca}$ than irtually all $\mathrm{Ca}$, except that bound in $\mathrm{Ca}$ (Gallaher and Jones, 1976). relatively soluble $\mathrm{Ca}$ salts in the cytoassociated with maintenance of membran selectivity, cell wall development, cytoplasmic streaming, intracellular messenger activty, and numerous other functions (Bush, indicate that Ca was not 1985). These data appear to be in excess; thus, Ca did not contribute to this disorder. Magnesium and $\mathrm{B}$ were slightly higher and Mn lower in from Charlie, but these difference

'Pawnee' kernels with necrosis had more $\mathrm{P}, \mathrm{Zn}$, and $\mathrm{Mn}$ than normal kernels (Table 4). Basal segments of necrotic kernels had more etic acid-extractable and water-soluble $\mathrm{Ca}$ than distal segments or normal kernels. Similarly, the basal segment from necrotic
Elemental concentrations of $\mathrm{P}, \mathrm{K}, \mathrm{Zn}$, and those from Ardmore. Acetic acid extracts ater extraction primarily removes ionic $\mathrm{Ca}$ 
Table 5. The influence of nitrogen treatment on pecan leaf elemental concentration in July.

\begin{tabular}{|c|c|c|c|c|c|c|c|c|c|}
\hline \multirow[b]{2}{*}{$\mathrm{Yr}$} & \multirow{2}{*}{$\begin{array}{l}\mathrm{N} \text { rate }\left(\mathrm{g} / \mathrm{cm}^{2}\right. \\
\text { cross-sectional } \\
\text { trunk area })\end{array}$} & \multicolumn{5}{|c|}{$\begin{array}{l}\text { Elemental concn } \\
\text { (\% dry wt.) }\end{array}$} & \multicolumn{3}{|c|}{$\begin{array}{l}\text { Elemental concn } \\
\text { ( } \mu \mathrm{g} / \mathrm{g} \text { dry wt.) }\end{array}$} \\
\hline & & $\mathrm{N}$ & $\mathrm{P}$ & $\mathrm{K}$ & $\mathrm{Ca}$ & $\mathrm{Mg}$ & $\mathrm{Zn}$ & $\mathrm{Fe}$ & $\mathrm{Mn}$ \\
\hline \multirow[t]{3}{*}{2002} & None & $2.89^{\mathrm{x}}$ & 0.161 & 0.92 & 1.26 & 0.54 & 70 & 61 & 999 \\
\hline & $0.8^{\mathrm{z}}$ & 2.87 & 0.160 & 0.95 & 1.34 & 0.54 & 67 & 62 & 999 \\
\hline & $1.6+1.6+1.2^{y}$ & 2.91 & 0.160 & 0.90 & 1.34 & 0.55 & 73 & 59 & 1059 \\
\hline \multirow[t]{3}{*}{2003} & None & 2.69 & 0.120 & 1.13 & 1.54 & 0.61 & 49 & 65 & 1118 \\
\hline & 0.8 & 2.59 & 0.114 & 1.11 & 1.53 & 0.58 & 48 & 61 & 1052 \\
\hline & $1.6+1.6+1.2$ & 2.71 & 0.113 & 1.10 & 1.64 & 0.61 & 49 & 63 & 1188 \\
\hline \multirow[t]{3}{*}{2004} & None & $2.60 \mathrm{~b}$ & 0.122 & 0.97 & 1.42 & 0.61 & 196 & 59 & 974 \\
\hline & 0.8 & $2.61 \mathrm{~b}$ & 0.118 & 0.96 & 1.50 & 0.60 & 210 & 56 & 897 \\
\hline & $1.6+1.6+1.2$ & $2.75 \mathrm{a}$ & 0.116 & 0.95 & 1.49 & 0.60 & 198 & 54 & 1074 \\
\hline \multirow[t]{3}{*}{2005} & None & 2.69 & $0.125 \mathrm{a}$ & $1.14 \mathrm{ab}$ & 1.30 & 0.56 & 96 & 58 & $756 a b$ \\
\hline & 0.8 & 2.76 & $0.127 \mathrm{a}$ & $1.17 \mathrm{a}$ & 1.27 & 0.54 & 95 & 59 & $699 \mathrm{~b}$ \\
\hline & $1.6+1.6+1.2$ & 2.79 & $0.120 \mathrm{~b}$ & $1.07 \mathrm{~b}$ & 1.31 & 0.54 & 97 & 59 & $871 \mathrm{a}$ \\
\hline \multirow[t]{3}{*}{2006} & None & 2.81 & $0.115 \mathrm{a}$ & 0.90 & 1.70 & 0.67 & 80 & 56 & 1098 \\
\hline & 0.8 & 2.85 & $0.114 \mathrm{a}$ & 0.87 & 1.65 & 0.65 & 77 & 55 & 917 \\
\hline & $1.6+1.6+1.2$ & 2.81 & $0.110 \mathrm{~b}$ & 0.89 & 1.68 & 0.65 & 79 & 55 & 1205 \\
\hline
\end{tabular}

${ }^{\mathrm{z}}$ Applied second week in March.

${ }^{y}$ Applied second week in March, first week in June, and first week in September, respectively.

${ }^{x}$ Means within years and columns followed by the same letter are not significantly different at the $5 \%$ level

by Duncan's multiple range test. Means within years and columns without letters were not significantly different.
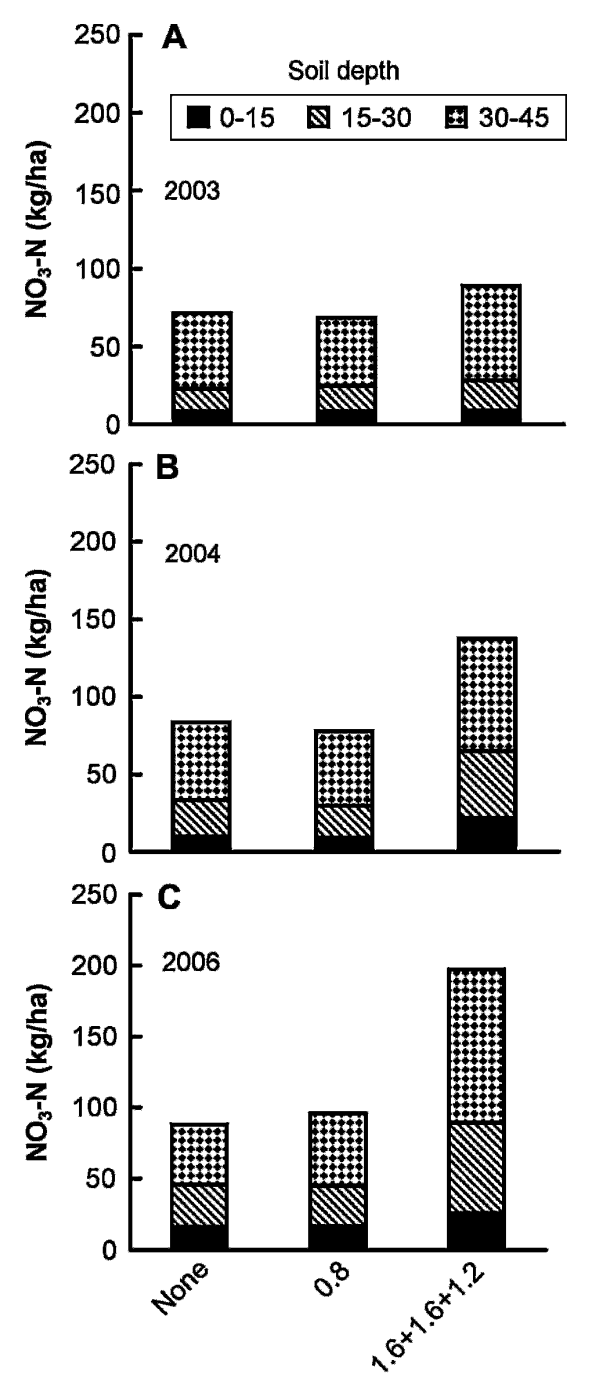

Nitrogen rate $\left(\mathrm{g} / \mathrm{cm}^{2}\right.$ crosssectional trunk area)

Fig. 3. The effect of nitrogen treatment on soil $\mathrm{NO}_{3}-$ $\mathrm{N}$ concentrations at three soil depths $(\mathbf{A}) 1,(\mathbf{B}) 2$, and (C) 4 years after the study was initiated. The single $\mathrm{N}$ application rate was applied the second week in March, and the split rate was applied the second week in March, first week in June, and the first week in September, respectively. kernels had more B than the distal segment or either segment from normal kernels. Higher elemental concentrations in necrotic kernels basal segments does not appear sufficient to cause damage. The elevated concentrations of some elements, particularly those with limited phloem mobility, combined with a larger fruit size (Table 2) suggests that transpiration rates and xylem transport to affected fruit was higher.

Soil tests indicated all elements tested were within the normal range (Smith, 1991), except $\mathrm{K}$ was slightly low $(334,328$, and $297 \mathrm{~kg} \cdot \mathrm{ha}^{-1}$ at $0-15,15-30$, and $30-45-\mathrm{cm}$ depths, respectively) and $\mathrm{NO}_{3}-\mathrm{N}$ was higher than expected $\left(9,58\right.$, and $92 \mathrm{~kg} \cdot \mathrm{ha}^{-1}$ at $0-15$, 15-30, and 30-45-cm depths, respectively). deviations.
Irrigation water samples were high in $\mathrm{NO}_{3}$, averaging $34 \pm 1(\bar{x} \pm \mathrm{SD}) \mathrm{mg} \cdot \mathrm{L}^{-1} \mathrm{NO}_{3}-\mathrm{N}$ over the irrigation season. Other components of the irrigation water were within acceptable limits (data not shown). Based on these results, we suspected that excess $\mathrm{N}$ might be either contributing to or the cause of kernel necrosis.

Nitrogen rate experiment results. Nitrogen applied during irrigation was 142, 191, 127,147 , and $190 \mathrm{~kg} \cdot \mathrm{ha}^{-1} \mathrm{~N}$ in 2002 through 2006 , respectively, as $\mathrm{NO}_{3}$ from the groundwater. This $\mathrm{N}$ was applied to all trees in the study, regardless of the supplemental $\mathrm{N}$ treatment.

Supplemental $\mathrm{N}$ affected leaf $\mathrm{N}$ concentration only one time during the 5-year study (Table 5). In 2004, trees receiving the highest nitrogen rate had the highest $\mathrm{N}$ concentration. Minimal affects of supplemental $\mathrm{N}$ on leaf $\mathrm{N}$ concentration suggests that additional $\mathrm{N}$ absorption was suppressed (Imsande and Touraine, 1994) or excess $\mathrm{N}$ was volatilized from the plant (Stutte et al., 1979). Other elemental concentrations were rarely affected by treatment. Elemental concentrations were within normal ranges, except $\mathrm{P}$ was slightly low 3 years and $\mathrm{Zn}$ was low during 1 year (Smith, 1991).

Nitrate in the soil accumulated throughout the study (Fig. 3). Accumulation occurred even when the only $\mathrm{N}$ received was from the $\mathrm{NO}_{3}$-contaminated irrigation water. In 2003, $\mathrm{NO}_{3}-\mathrm{N}$ totaled $71 \mathrm{~kg} \cdot \mathrm{ha}^{-1}$ in the upper $45 \mathrm{~cm}$ of soil during January when $\mathrm{N}$ was withheld, except that applied in the irrigation water. By Jan. 2006, $\mathrm{NO}_{3}-\mathrm{N}$ had accumulated to $88 \mathrm{~kg} \cdot \mathrm{ha}^{-1}$ in the upper $45 \mathrm{~cm}$ of soil, a $24 \%$ increase in 3 years. The producer's N

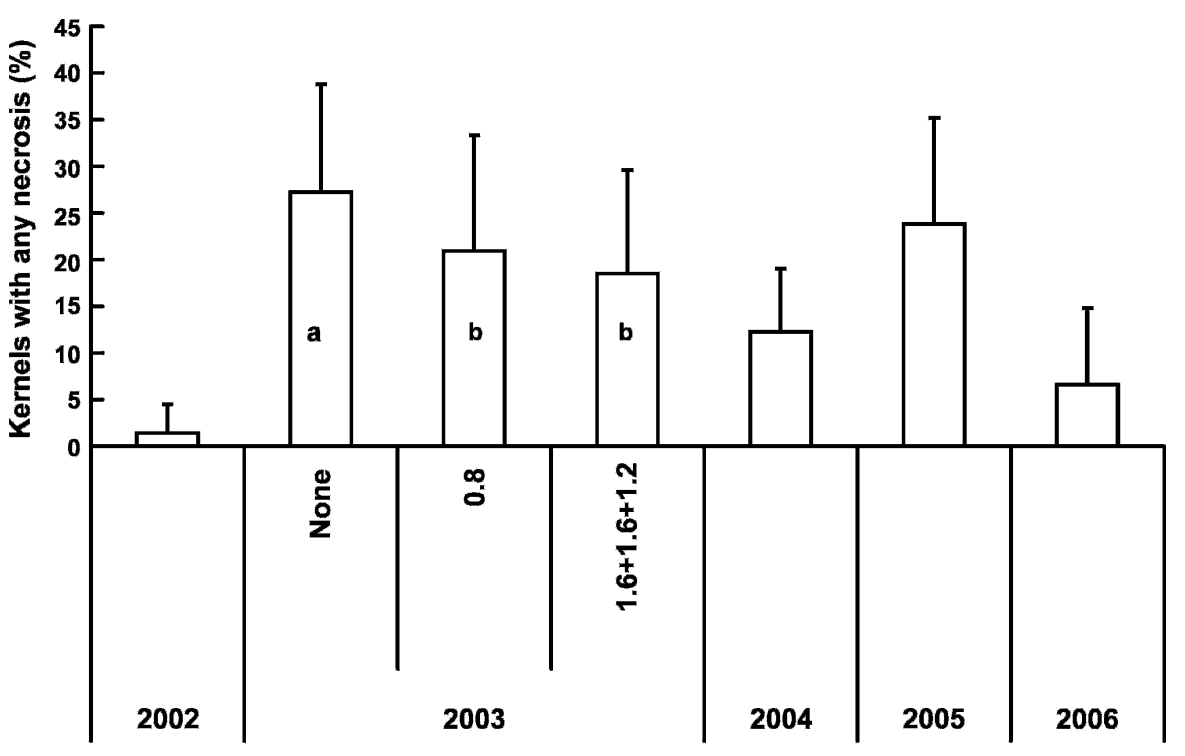

$\mathrm{N}$ treatment (g/cm2 cross-section trunk area) / year

Fig. 4. The influence of nitrogen treatment and year on 'Pawnee' pecan kernels with any necrosis (grade 2 or greater). In 2003, treatments with the same letter are not significantly different by Duncan's multiple range test, 5\% level. The single $\mathrm{N}$ application rate was applied the second week in March, and the split rate was applied the second week in March, the first week in June, and the first week in September, respectively. Nitrogen treatment did not affect kernels with any necrosis in 2002, 2004, 2005, and 2006 and data are pooled over $\mathrm{N}$ treatment for each year. Vertical bars are standard 
application rate resulted in $197 \mathrm{~kg} \cdot \mathrm{ha}^{-1}$ of $\mathrm{NO}_{3}-\mathrm{N}$ in the upper $45 \mathrm{~cm}$ of soil. Concentrations of $\mathrm{NO}_{3}-\mathrm{N}$ increased with soil depth, suggesting that $\mathrm{NO}_{3}-\mathrm{N}$ was even higher deeper in the soil. These were extremely high concentrations of $\mathrm{NO}_{3}-\mathrm{N}$ during January. Because $\mathrm{NO}_{3}$ accumulated in the soil, even without supplemental $\mathrm{N}$ application, rates from the irrigation water exceed $\mathrm{N}$ absorbed by the tree, immobilized by other organisms, leached, and volatilized.

The percentage of kernels with any necrosis (grade 2 or higher; Fig. 1) or severe necrosis (grade 4) was calculated. The percentage of kernels with any necrosis varied widely among years, ranging from $1.4 \%$ in 2002 to $22.2 \%$ in 2003 (Fig. 4). Nitrogen treatment only affected the percentage of kernels with any necrosis 1 year during the study. In 2003, trees not receiving supplemental $\mathrm{N}$ had more kernel necrosis than the other treatments. Nitrogen treatments did not affect the amount of kernels with severe necrosis (data not shown). Kernels with severe necrosis ranged from $1 \%$ in 2002 to $7.5 \%$ in 2003 (Fig. 5). These results do not necessarily eliminate excess $\mathrm{N}$ contributing to the problem or as a causal agent because $\mathrm{NO}_{3}$ in the irrigation water exceeded tree demand (Fig. 3).

Regression of leaf elemental concentrations, ratios of leaf $\mathrm{N}$ with leaf $\mathrm{Ca}, \mathrm{Mg}, \mathrm{P}$, or $\mathrm{K}$, and yield with the percentage of kernels with necrosis resulted in some models within and among years that accounted for up to $50 \%$ of the variation in the data (data not shown). In most cases, models contained several components, each with a small partial

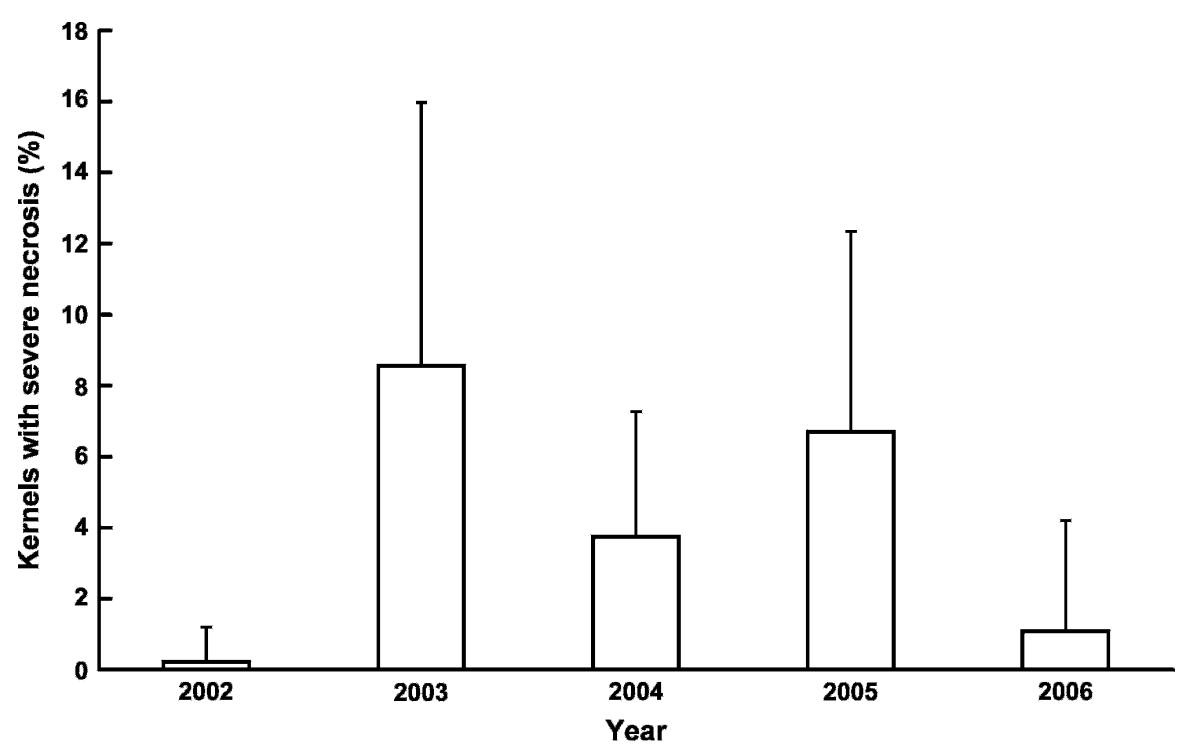

Fig. 5. The influence of year on 'Pawnee' pecan kernels with severe necrosis (grade 4). Data are pooled over $\mathrm{N}$ treatments. Vertical bars are SD.

Table 6. The influence of nitrogen treatment on pecan yield, weight per nut, and kernel percentage.

\begin{tabular}{|c|c|c|c|c|}
\hline Yr & $\begin{array}{c}\mathrm{N} \text { rate } \\
\left(\mathrm{g} / \mathrm{cm}^{2} \text { cross-sectional trunk area) }\right.\end{array}$ & $\begin{array}{c}\text { Yield } \\
(\mathrm{kg} / \text { tree })\end{array}$ & Wt/nut (g) & $\begin{array}{c}\text { Kernel } \\
\text { yield }(\%)\end{array}$ \\
\hline \multirow[t]{3}{*}{2002} & None & $30^{\mathrm{x}}$ & 8.5 & 58.14 \\
\hline & $0.8^{\mathrm{z}}$ & 29 & 8.4 & 57.96 \\
\hline & $1.6+1.6+1.2^{\mathrm{y}}$ & 27 & 8.4 & 58.45 \\
\hline \multirow[t]{3}{*}{2003} & None & 11 & 10.7 & 56.05 \\
\hline & 0.8 & 12 & 10.6 & 56.50 \\
\hline & $1.6+1.6+1.2$ & 14 & 10.4 & 56.85 \\
\hline \multirow[t]{3}{*}{2004} & None & 37 & 8.7 & 57.35 \\
\hline & 0.8 & 38 & 8.7 & 57.21 \\
\hline & $1.6+1.6+1.2$ & 35 & 8.8 & 57.72 \\
\hline \multirow[t]{3}{*}{2005} & None & 24 & 9.5 & 59.46 \\
\hline & 0.8 & 24 & 9.6 & 59.08 \\
\hline & $1.6+1.6+1.2$ & 29 & 9.4 & 59.76 \\
\hline \multirow[t]{4}{*}{2006} & None & 21 & 9.1 & 56.93 \\
\hline & 0.8 & 21 & 8.8 & 57.14 \\
\hline & $1.6+1.6+1.2$ & 18 & 9.1 & 56.86 \\
\hline & & Cumulative & \multicolumn{2}{|c|}{ Average } \\
\hline \multirow[t]{3}{*}{ Summary } & None & 123 & 9.3 & 57.73 \\
\hline & 0.8 & 125 & 9.2 & 57.70 \\
\hline & $1.6+1.6+1.2$ & 122 & 9.2 & 58.00 \\
\hline
\end{tabular}

${ }^{\mathrm{z}}$ Applied second week in March.

${ }^{y}$ Applied second week in March, first week in June, and first week in September, respectively.

${ }^{\mathrm{x}}$ No treatments were significantly different.
$\mathrm{R}^{2}$. Examination of the various models revealed few components were contained in more than three of the models (12 models, one for each year and pooled over years for any kernel necrosis and severe necrosis). This suggests that none of the model components were consistently related to kernel necrosis.

Yield was unaffected by treatment during the study (Table 6). Nitrogen depletion by large crops has been proposed to contribute to pecan alternate bearing (Goff et al., 2001; Kraimer et al., 2004; Wood, 2001). In this study, nitrogen was supplied throughout the growing season in excess, but alternate bearing was apparent. For instance, yield was $57 \%$ lower in 2003 than 2002 and in 2005 yield was $30 \%$ lower than in 2004 . These data demonstrate that abundant $\mathrm{N}$ supplied throughout the growing season did not prevent alternate bearing.

Weight of individual nuts and kernel percentage were unaffected by treatment, although they varied among years (Table 6). Neither shoot length nor trunk diameter was affected by $\mathrm{N}$ treatment (data not shown).

A previously unrecognized disorder of pecan kernels, kernel necrosis, is a severe problem on 'Pawnee' nuts at the orchard in Charlie, TX. It was identified in other orchards, but at low levels. Two other cultivars frequently have similar symptoms, 'Choctaw' and 'Oklahoma'. 'Pawnee' is currently the most planted cultivar in Oklahoma and is popular over most of the U.S. pecan growing regions. 'Choctaw' is popular in southern Oklahoma and is found elsewhere in the United States. 'Oklahoma' is an old cultivar with few remaining producing trees. Our results have failed to identify the cause of this problem. However, they serve as a basis for future studies. This study also demonstrated that alternate bearing remains a problem even when $\mathrm{N}$ is in abundant supply throughout the growing season.

\section{Literature Cited}

Board of Regents Oklahoma University. 2006. Oklahoma AgWeather. http://agweather. mesonet.ou.edu/. Accessed 14 Aug 2007.

Bush, D.S. 1993. Regulation of cytosolic calcium in plants. Plant Physiol. 103:7-13.

Dible, W.T., E. Truog, and K.C. Berger. 1954 Boron determination in soils and plants. Anal. Chem. 26:418-421.

English, J.E. and A.V. Barker. 1982. Water-soluble calcium in $\mathrm{Ca}$-efficient and $\mathrm{Ca}$-inefficient tomato strains. HortScience 17:929-931.

Faust, M., C.B. Shear, and C.B. Smith. 1968. Investigation of corking disorders of apples. II. Chemical composition of affected tissues. J. Amer. Soc. Hort. Sci. 92:82-88.

Gallaher, R.N. and J.B. Jones, Jr. 1976. Total, extractable, and oxalate calcium and other elements in normal and mouse ear pecan tree tissue. J. Amer. Soc. Hort. Sci. 101:692-696.

Goff, B., M. Nesbitt, and C. Browne. 2001. Late season fertilization: An exciting new development for the pecan industry. Proc. Southeastern Pecan Growers' Assn. 94:91-93.

Harris, M.K. and D.R. Ring. 1979. Biology of pecan weevil from oviposition to larval emergence. Southwest. Entomologist 4:73-85. 
Hepler, P.K. and R.O. Wayne. 1985. Calcium and plant development. Ann. Rev. Plant Physiol. 36:397-439.

Horowitz, W. 1980. Official methods of analysis of the association of analytical chemists. 13th ed. Assn. Offic. Anal. Chemists, Washington, DC, p. 15 , section 2058 .

Imsande, J. and B. Touraine. 1994. N demand and the regulation of nitrate uptake. Plant Physiol. 105:3-7.

Kraimer, R.A., W.C. Lindemann, and E.A. Herrera. 2004. Recovery of late-season N-15labeled fertilizer applied to pecan. HortScience 39:256-260.
Olsen, S.R. and L.E. Sommers. 1982. Phosphorus, p. 404-430. In: A.L. Page, R.H. Miller, and D.R. Keeney (eds.). Methods of soil analysis. Part 2. Chemical and microbiological properties. Amer. Soc Agron. and Soil Sci. Soc. Amer., Madison, WI.

Smith, M.W. 1991. Pecan nutrition, p. 152-158. In: B.W. Wood and J.A. Payne. (eds.). Pecan husbandry: Challenges and opportunities. U.S. Dept. Agr., Agr. Res. Serv., ARS-96.

Smith, M.W. and J.C. Gallott. 1990. Mechanical thinning of pecan fruit. HortScience 25: $414-416$.
Stutte, C.A., R.T. Weiland, and A.R. Blem. 1979. Gaseous nitrogen loss from soybean foliage. Agron. J. 71:95-97.

Thompson, T.E. and F. Young. 1985. Pecan cultivars-Past and present. Texas Pecan Growers Assn., Inc., College Station, TX.

Wood, B.W. 2001. Managing nitrogen in pecan orchards. Proc. Southeastern Pecan Growers' Assn. 94:153-159.

Yates, I.E., W.L. Tedders, and D. Sparks. 1991. Diagnostic evidence of damage on pecan shells by stink bugs and coreid bugs. J. Amer. Soc. Hort. Sci. 116:42-46. 